\title{
IDENTIFIKASI KESULITAN FUNGSIONAL SISWA SDN PERESAK BEBUAK KECAMATAN KOPANG KABUPATEN LOMBOK TENGAH
}

\author{
Itsna Oktaviyanti, Nassarudin, Heri Setiawan*, Ilham Syahrul Jiwandono \\ Pendidikan Guru Sekolah Dasar, FKIP UNRAM \\ *Corresponding Author: heri_setiawan@unram.ac.id
}

\section{Article History}

Received : Januari $13^{\text {th }}, 2021$

Revised : February $10^{\text {th }}, 2021$

Accepted : March 13 ${ }^{\text {th }}, 2021$

Published : May 05 ${ }^{\text {th }}, 2021$

\begin{abstract}
Provinsi Nusa Tenggara Barat merupakan salah satu provinsi dengan jumlah masyarakat yang mengalami kesulitan fungsional cukup tinggi di Indonesia. Salah satu wilayah yang menjadi sorotan adalah di Kabupaten Lombok Tengah. Diperlukan identifikasi serta penanganan yang serius agar angka tersebut turun. Tujuan dari penelitian ini adalah untuk mengetahui ragam jenis kesulitan fungsional yang dialami oleh siswa di Kabupaten Lombok Tengah, khususnya di SDN Peresak Bebuak. Metode penelitian menggunakan deskriptif kualitatif. Lokasi penelitian di SDN Peresak Bebuak, Kecamatan Kopang, Kabupaten Lombok Tengah. Waktu pelaksanaan penelitian yaitu semester ganjil tahun pelajaran 2020/2021. Subjek penelitian ini ialah seluruh siswa kelas IV SD di SDN Peresak Bebuak sebanyak 27 siswa. Penelitian ini menggunakan 3 bentuk instrumen yaitu; pertama, Profil Belajar Siswa (PBS), kedua, pedoman wawancara dengan guru dan orang tua, ketiga, dokumen pendukung seperti hasil belajar siswa, hasil karya siswa, catatan pribadi siswa, ataupu catatan riwayat kesehatan siswa. Validasi data menggunakan informant review atau umpan balik dari informan. Analisis data menggunakan reduksi data, sajian data, dan penarikan kesimpulan atau verivikasi. Hasil penelitian ini. Berdasar hasil observasi, wawancara, dan studi dokumentasi diperoleh data bahwa $8(4,5 \%)$ siswa SDN Peresak Bebuak masuk kategori siswa dengan kesulitan fungsional. 7 diantaranya masuk kategori kesulitan intelektual baik ringan maupun sedang. 1 siswa masuk kategori kesulitan belajar spesifik. Hasil penelitian hanya sebatas pendataan dengan PBS dan hasil wawancara saja, sehingga perlu ditindaklanjuti dengan asesmen lanjutan oleh ahli baik dari dokter, psikolog, maupun guru SLB dan praktisi lain yang berkompeten di bidang siswa berkebutuhan khusus.
\end{abstract}

Keywords: Identifikasi, kesulitan fungsional, SDN Peresak Bebuak.

\section{PENDAHULUAN}

Provinsi Nusa Tenggara Barat merupakan salah satu provinsi dengan jumlah masyarakat yang mengalami kesulitan fungsional cukup tinggi di Indonesia. Salah satu wilayah yang menjadi sorotan adalah di Kabupaten Lombok Tengah. Diperlukan penanganan yang serius agar angka tersebut turun. Laporan dari World Report on Disability (WHO, 2011) menunjukkan bahwa Sekitar 15 dari 100 orang di dunia mengalami kesulitan fungsional. Antara 24 dari 100 orang mengalami kesulitan fungsional berat. Dengan meningkatnya usia harapan hidup terdapat kecenderungan meningkatnya masyarakat dengan kesulitan fungsional, apalagi jika disertai pelayanan kesehatan yang kurang memadai. Terjadinya kesulitan fungsional yang dialami oleh masyarakat juga dapat disebabkan penyakit dan kondisi kesehatan tertentu, bencana alam, kecelakaan, dan penyebab lainnya.

Sejak awal Pemerintah Indonesia telah melakukan upaya untuk meningkatkan pemahaman dan kesadaran akan hal tersebut. Sebagai salah satu negara penandatangan konvensi tentang Hak-Hak tentang disabilitas, Indonesia mengesahkan Undang-Undang Nomor 19 Tahun 2011 tentang Pengesahan Convention on the Rights of Persons with Disabilities (Konvensi Hak-hak Penyandang Disabilitas), yang menunjukkan komitmen dan kesungguhan Pemerintah Indonesia untuk menghormati, melindungi, dan memenuhi hak penyandang kesulitan fungsional yang pada akhirnya diharapkan dapat meningkatkan kesejahteraan bagi masyarakat yang mengalami kesulitan fungsional.

Indonesia juga memiliki UndangUndang Nomor 8 Tahun 2016 tentang 
Penyandang disabilitas yang menggantikan Undang-Undang Nomor 4 Tahun 1997 tentang Penyandang Cacat yang dipandang belum berperspektif hak asasi manusia, lebih bersifat belas kasihan dan pemenuhan hak penyandang kesulitan fungsional masih dinilai sebagai masalah sosial yang kebijakan pemenuhan haknya baru bersifat jaminan sosial, rehabilitasi sosial, bantuan sosial, dan peningkatan kesejahteraan sosial. Penyandang kesulitan fungsional seharusnya mendapatkan kesempatan yang sama dalam upaya mengembangkan dirinya melalui kemandirian sebagai manusia yang bermartabat.

Sesuai undang-undang tersebut, definisi penyandang kesulitan fungsional adalah setiap orang yang mengalami keterbatasan fisik, intelektual, mental, dan/atau sensorik dalam jangka waktu lama yang dalam berinteraksi dengan lingkungan dapat mengalami hambatan dan kesulitan untuk berpartisipasi secara penuh dan efektif dengan warga negara lainnya berdasarkan kesamaan hak.

Guru di sekolah dasar, khusunya di Kabupaten Lombok Tengah masih kesulitan mengidentifikasi kesulitan fungsional yang dialami oleh siswa. Oleh sebab itu, diperlukan identifikasi sehingga nantinya memudahkan guru untuk menangani. Ragam penyandang kesulitan fungsional meliputi penyandang kesulitan fungsional fisik, intelektual, mental, dan/atau sensorik, yang dapat dialami secara tunggal, ganda, atau multi dalam jangka waktu lama yang ditetapkan oleh tenaga medis sesuai dengan ketentuan peraturan perundang-undangan.

Urgensi dalam penelitian ini adalah mengetahui ragam jenis dan tingkat kesulitan fungsional dari kegiatan identifikasi yang dilakukan, khususnya di SDN Peresak Bebuak yang kemudian akan ditindaklanjuti penanganannya agar angka kesulitan fungsional di Provinsi Nusa Tenggara barat turun.

Perumusan masalah berdasar latar belakang diatas adalah sebagai berikut: (1) Apa jenis kesulitan fungsional yang dialami oleh siswa SDN Peresak Bebuak?; (2) Apa rekomendasi yang akan diberikan kepada siswa yang mengalami kesulitan fungsional di SDN Peresak Bebuak?

\section{METODE}

Berdasarkan permasalahan yang diajukan dalam penelitian ini, yang cocok dan relevan adalah penelitian kualitatif deskriptif.
Dengan penelitian ini diharapkan dapat mengungkap berbagai informasi kualitatif dengan deskripsi-analisis yang teliti dan penuh makna, yang juga tidak menolak informasi kuantitatif dalam bentuk angka maupun jumlah (Creswell, 2009). Penelitian ini mengambil lokasi di SDN Peresak Bebuak, Desa Bebuak, Kecamatan Kopang, Kabupaten Lombok Tengah. Waktu pelaksanaan penelitian yaitu semester ganjil tahun pelajaran 2020/2021. Subjek penelitian ini ialah seluruh siswa di SDN Peresak Bebuak sebanyak 172 siswa. Penelitian ini menggunakan 3 bentuk instrumen yaitu; pertama, Profil Belajar Siswa (PBS), kedua pedoman wawancara dengan guru dan orang tua, ketiga, dokumen pendukung seperti hasil belajar siswa, hasil karya siswa, catatan pribadi siswa, ataupu catatan riwayat kesehatan siswa.

Untuk menjamin validitas data peneliti mengggunakan teknik informant review atau umpan balik dari informan (Milles dan Hubberman, (2010). Selain itu peneliti juga menggunakan teknik triangulasi untuk lebih memvalidkan data (Paton, 1980). Teknik triangulasi yang penulis gunakan dalam penelitian ini adalah triangulasi sumber, triangulasi metode, dan triangulasi teori.

Teknik analisis yang digunakan dalam penelitian ini adalah analisis interaktif (Miles dan Huberman, 2010). Dalam model analisis ini, tiga komponen analisisnya yaitu reduksi data, sajian data, dan penarikan kesimpulan atau verivikasi.

\section{HASIL DAN PEMBAHASAN}

\section{Hasil Pendataan Jenis Kesulitan Fungsional di SDN Peresak Bebuak}

Pada hakikatnya terdapat beberapa
tahapan yang harus dilakukan dalam memberikan layanan terhadap siswa denga kesulitan fungsional. Tahap pertama yang memiiki peran penting dalam mempersiapkan layanan terhadap siswa dengan kesulitan fungsional yaitu identifikasi. Proses identifikasi perlu dilakukan oleh guru agar dalam memberikan program lanjutan dapat disesuaikan dengan jenis kesulitan dan bantuan yang dibutuhkan oleh siswa.

Pelaksanaan identifikaasi kesulitan fungsional dilakukan dengan menggunakan Instrumen Profil Belajar Siswa (PBS). Hal ini sesuai dengan Surat Direktur Pembinaan Pendidikan Khusus Nomor 3179/D6.1.1/PR/2019 tanggal 22 Agustus 2019 
perihal Permbuatan Profil Belajar Siswa Pada Satuan Pendidikan Penyelenggara Pendidikan Inklusif. Profil belajar siswa (PBS) merupakan instrumen pendataan awal yang dapat digunakan oleh guru kelas umum untuk mendata siswa yang diduga mengalami kesulitan fungsional (Setiawan dkk, 2020b:172). PBS dikembangkan oleh tim Kemendikbud bekerja sama dengan Kedubes Australia melalui program Inovasi Indonesia serta TASS (Kemendikbud, 2019). PBS terdiri atas 9 komponen utama yaitu: (1) Identifikasi Ragam Disabilitas; (2) Alat Bantu Khusus; (3) Pergerakan di lingkungan sekolah; (4) Kelebihan atau Kemampuan; (5) Belajar dan Dukungan yang dibutuhkan; (6) Informasi Kesehatan, Diagnosa dan Pengobatan atau Penanganan; (7) Informasi Lain; (8) Kesimpulan Sementara; dan (9) Program Pembelajaran Individual (PPI). Contoh tampilan PBS dapat dilihat pada gambar berikut.

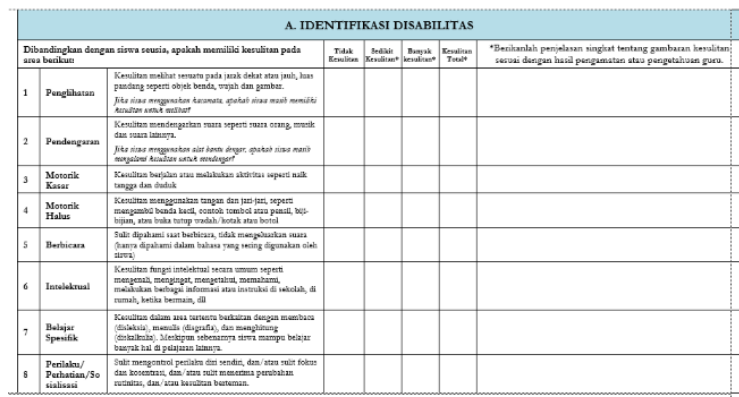

\section{Gambar 4.1. Contoh Tampilan Profil Belajar Siswa (PBS)}

Pelaksanaan pedataan dilakukan pada bulan Maret - April 2020 di SDN Peresak bebuak, Kopang. Tim peneliti melaksanakan pendampingan dan observasi di kelas mula dari kelas 1 hingga kelas 6. Pendataan dilakukan bersama guru agar hasil yang didapatkan akurat dan sesuai keadaan riil di Lapanagan.

Berdasarkan hasil observasi selama penelitian penelitian dilakukan dapat ditemukan bahwa siswa yang teridentifikasi berkebutuhan khusus sebanyak 8 siswa dari total 174 siswa. Jumlah tersebut jika dibandingkan dengan jumlah siswa secara keseluruhan tergolong cukup kecil. Berikut ini dapat disajikan perbandingan siswa berkesulitan fungsional denngan siswa lain di SDN Peresak Bebuak:

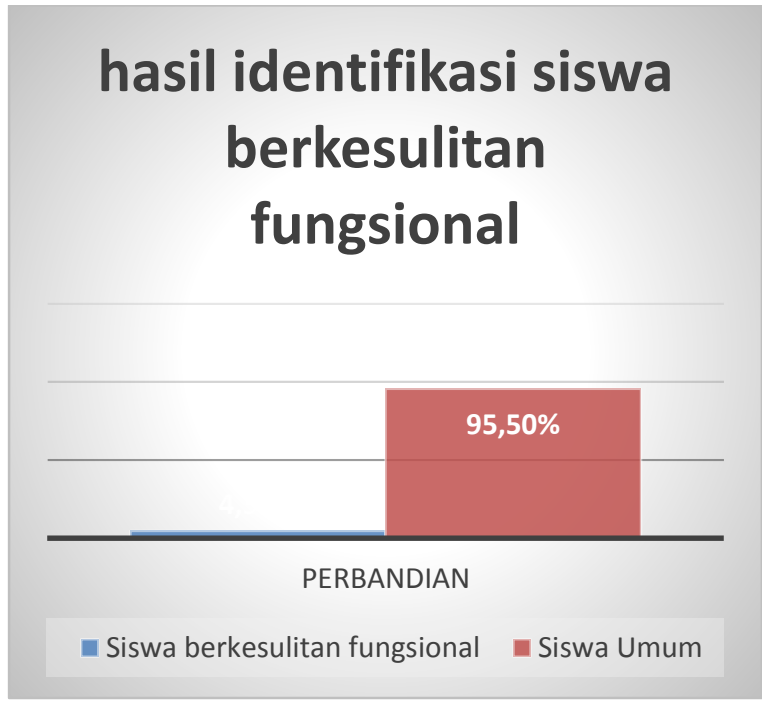

Gambar 4.2. Perbandingan siswa berkesulitan fungsionl di SDN Peresak Bebuak

Berdasarkan gambar di atas dapat diketahui bahwa jumlah siswa dengan kesulitan fungional 4,5 \% dari jumlah siswa secara keseluruhan yaitu 8 siswa. Sedangkan sisanya adalah siswa umum sebanyak 95,5\% atau 166 dari 172 siswa secara keseluruhan. Dari 8 siswa yang memiliki kesulitan fungsional jika diklasifikasikan menurut jenis hambatannya dapat dilihat pada grafik berikut.

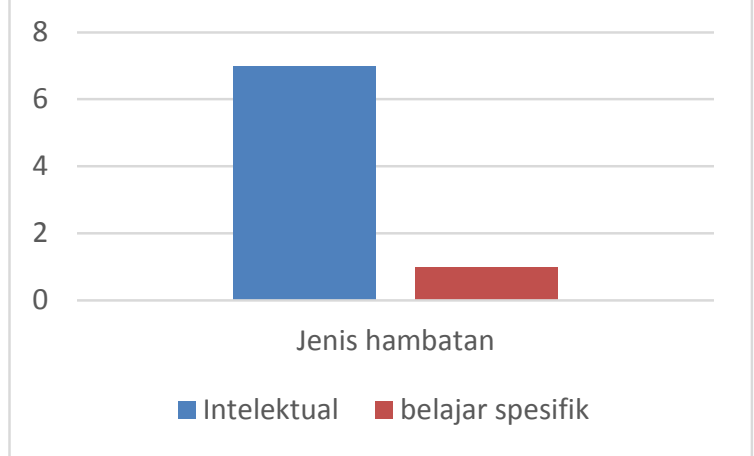

\section{Gambar 4.3. Sebarab Siswa Berdasar Jenis Kesulitan Fungsional di SDN Peresak Bebuak}

\section{Ragam dan Tingkat Kesulitan Fungsional Siswa di SDN Peresak Bebuak Berdasar Hasil Identifikasi}

Dari total 8 siswa, paling dominal menunjukkan gejala/kecenderungan memiliki hambatan intelektual. Kesulitan fungsi intelektual secara umum ditandai dengaan kesulitan siswa dalam mengenali, mengingat, mengetahui, memahami, melakukan berbagai 
informasi atau instruksi di sekolah, di rumah, ketika bermain, dll (Kemendikbud, 2019). 7 siswa tersebut tersebar di beberapa jenjang kelas dari kelas 1 - kelas 6.

Dua siswa berkesulitan intelektual sedang terdapat pad kelas 1 dan kelas 3. Gejala umum yang ditunjukkan yaitu jika dibandingkan dengan anak lain di usia yang sama, anak memiliki banyak kesulitan terkait belajar, keterampilan akademik dan konsep atau, kesulitan memahami beberapa instruksi/langkah dalam suatu tugas (Kemdikbud, 2019). Siswa ini membutuhkan waktu lebih banyak dalam menyelsaikan tugastugas yang diberikan guru.

Selain itu, siswa juga mengalami kesulitan dalam mengingat instruksi. Ketika diberikan tugas, siswa harus ditunggui oleh gurunya agar siswa mapu menyelesaikan tugas tersebut. Meskipun telah mendapat pendampingan, seringkali siswa masih mengaalami kendal alam memahami dan menyelsaikan tugas serta materi.

Pendampingan yang sudah dilakukan oleh guru kelas $1 \& 3$ yaitu melalui perencanaan dan penyiapan pembelajaran mulai dari penyesuaian tujuan pembelajaran, indikator, materi, serta metode dan media pembelajaran. Guru sedikit menurunkan capaian indikator dan tujuan sesaui dengan kemampuan yang dimiliki siswa dengan kesulitan fungsional tersebut. Selain itu guru juga memanfaatkan pula media pembelajaran dan metode pembelajaran yang bervariasi agar minat siswa meningkat, sehingga pemahaman dan daya tahan pengetahuannya meningkat.

Lima dari tujuh siswa lain mengalami kesulitan intelektual ringan. Kelimanya tersebar di kelas 4, 5, dan 6. Menurut Kemdikbud (2019), siswa dengan kesulitan fungsional intelektual ringan jika dibandingkan dengan anak lain di dalam kelas, anak membutuhkan beberapa bantuan dan/atau tambahan waktu namun dapat dilakukan secara mandiri.

Hal ini juga terlihat selama observasi, dimana siswa lebih lamban dalam menerima dan menyelsaikan materi maupun tugas. Jika dibandingkan dengan teman sebayanya, siswa membutuhkan waktu yang lebih banyak. Hanya saja, siswa masih mampu untuk menyelesaikan tugas secara mandiri. Tidak membutuhkan banyak bantuan seperti siswa dengan kesulitan intelektual sedang dan total. Namun disisi lain, berdsar penuturan guru siswa juga seringkali kehilangan fokus saat pembelajaran. Karena kesulitan yang dialami menyebabkan siswa tersebut mengganggu dan mengajak siswa lain bermaain/mengobrol d kelas.
Pendampingan yang sudah dilakukan oleh guru kelas 4, 5, \& 6 yaitu melalui perencanaan dan penyiapan pembelajaran mulai dari penyesuaian tujuan pembelajaran, indikator, materi, serta metode dan media pembelajaran. Guru sedikit menurunkan capaian indikator dan tujuan sesaui dengan kemampuan yang dimiliki siswa dengan kesulitan fungsional tersebut. Selain itu guru juga memanfaatkan pula media pembelajaran dan metode pembelajaran yang bervariasi agar minat siswa meningkat, sehingga pemahaman dan daya tahan pengetahuannya meningkat. Guru juga menyesuaikan tingkat soal yang dikerjakan siswa agar sesuai dengan kemampuan siswa tersebut.

Selain upaya-upaya diatas, guru juga berupaya untuk mengatasi kesulitan siswa dengan kerjasama orang tua. Guru mengajak orang tua untuk berperan aktif dlam mendamppingi dan memastikan siswa beajar drumah sehingga siswa mengaalai perubahan yang positif. Gur juga sering melakukan roling tepat duduk serta seting kelas agar siswa dengan kesulitan fungsional intelktual dapa belajar maksimal.

Jenis kesulita kedua yang ditemukan selama observasi di SDN Peresak Bebuak Kopang yaitu kesulitan fungsional belajar spesifik. Kemdikbud (2019) siswa dengan kesulitan beljar spesifik jika dibandingkan dengan anak yang se -usia, anak memiliki kesulitan pada area tertentu meliputi area membaca, berhitung, memahami, menulis (seperti disleksia, diskalkulia). Kesulitan belajar specifik seperti disleksia mempengaruhi beberapa aspek dalam belajar. Anak-anak ini sering belajar keterampilan lain dengan sangat baik.

Hal ini terlihat saat observasi, bahwa siswa kelas II belum mampu meengenali huruf dan angka secara runtut. Siswa tersebut mengingat secara acak, dan sering kali terbalik urutannya baik abjad maupun angka. Selain itu, pada penulisan beberapa huruf dan keseluruhan angka, siswa menulis secara terbaik. Sehingga muncul dugaan anak mengalami disgrafia. Hal ini mengarah pada dugaan karena belum dilaksanakan asesmen lanjutan oleh ahli psikologi maupun guru SLB.

Hal-hal yang dilakukan oleh guru untuk membantu siswa tersebut yaitu dengan pendampingan individu dan media pembelajaran. Media yang digunakan yaitu media bigbook sehingga contoh tuilisan Abjad dan Angka dapat dilihat penuh oleh siswa dengan kesulitan belajar 
spesifik. Selain itu guru juga melakukan pendampingan dengan mendudukan siswa didepan dan dekat dengan guru, sehingga gur lebih mudah mengawasi.

Pada saat proses identifikasi belum ditemukan siswa yang mengalami kesulitan fungsional Penglihatan, Pendengaran, Motorik Kasar, Motorik Halus, Berbicara, Perilaku/ perhatian/ sosialisasi, maupun Emosi. Hal ini disebabkan karena identifikasi merupakan proses awal yang masih memerlukan tahapan selanjutnya. Terdapat tahapan yang harus dilakukan yaitu prosess asessmen dan program pembelajaran individual (PPI).

Selain itu, dalam proses identifikasi guru belum diampingi oleh pihak-pihak terkait yang berkompeten misal psikolog, guru SLB, maupun tenaga kesehatan khusus. Hal ini tentu mejadikan hasil pendataan masih sekedar data awal, dugaan kesulitan fungsional yang dialami siswa. Karena memang guru kelas tidak memiliki kewenangan menjudge atau melabeli siswa memiliki kelebihan/kekurangan. Hal ini sesuai dengan pasal 11 UU No. 70 Tahun 2009; Setiawan, dkk (2020a:242); Saputra (2016:11), Roza \& Rifma (2020:64) bahwa identifikasi dan asesmen dapat dilaksanakan oleh guru kelas dengan berkoordinasi dan bekerjasama dengan Guru Pendamping Khusus (GPK), guru mata pelajaran, psikolog, bahkan dokter spesialis dan orang tua untuk memperoleh hasil yang lebih objektif dan akurat.

Guru juga mengalami sedikit kendala dalam pelaksanaan idenifikasi menggunakan PBS. Hal ini dikarenakan PBS merupakan sebuah hal baru sehingga ada beberapa istilah dalam PBS yang asing. Hal ini juga ditemukan berdasar penelitian Setiawan (2020b:173) dimana guru SD juga mengalami kesulitan menggunakan PBS karena istilah-istilah, penjelasan, serta alat-alat yang dijabarkan didalam PBS masih asing bagi guru di lapangan.

\section{KESIMPULAN}

Berdasarkan hasil penelitian di atas dapat diberikan kesimpulan antara lain: 1 . Jumlah siswa yang teridentifikasi memiliki kesulitan fungsional 8 siswa atau 4,5\% dari jumlah peserta didik secara keseluruhan, 2. Jenis kebutuhan khusus yang ditemukan antara lain kesulitan fungsional intelektual ringan dan sedang, serta kesulitan fungsional belajar spesifik 3. Jenis kesulitan fungsional yang paling banyak ditemmukan pada siswa yaitu kesulitan fungsional intelektual.

Optimalisasi pendataa dengan melibatkan stake holder lain misalkan tenaga medis, psikolog, guru SLB, maupun orang tua sehingga diperoleh data lebih akurat. Pihdak sekolah juga dapat menguatkan hasil temuan dengan menindaklanjutinya kepada ahli sehingga siswa mmemperoleh penanganan cepat dan tepat sesuai kebutuhannya.

\section{UCAPAN TERIMA KASIH}

Terima kasih penulis sampaikan kepada kepala SDN Peresak Bebuak, Kecamatan Kopang, Kabupaten Lombok Tengah dan semua pihak yang telah membantu sehingga terselesaikannya tulisan ini.

\section{DAFTAR PUSTAKA}

Creswell, J. W. (2009). Research Design Qualitative, Quantitative, and Mixed Methods Approaches. London: SAGE Publications, Inc.

Direktorat Dikdasmen Pembinaan SLB. (2007). Identifikasi Anak Berkebutuhan Khusus. Kementerian Pendidikan dan Kebudayaan Republik Indonesia.

Efendi, M. (2006). Pengantar Psikopedagogik Anak Berkelainan. Jakarta : PT Bumi Aksara.

Hallahan, D. P \& Kauffman, J. M. (1988). Exeptional Children. New Jersey: Prentice Hall.

Hanafiah , N \& Suhana, C. (2009). Konsep Strategi Pembelajaran. Bandung: Refika Aditama.

Karten, T. J. (2008). Embracing Disability in the Classroom, Strategies to Maximize Students' Assets. Corwin Press a Sage Company: California.

Kemendikbud. (2019). Panduan Pendataan Siswa Penyandang disabilitas. (online) ( http://pgdikmen.kemdikbud.go.id/?ddown load=639), diakses tanggal 15 November 2020. 
Kirk, S. A. \& Gallagher. (1986). Educating Exceptional Children. Boston: Houghton Mifflin Company.

Kismawiyati, R. (2018). Identifikasi Anak Berkebutuhan Khusus Di Sekolah PAUD Kabupaten Jember. Jurnal Helper : 35 (1), $1-10$

Miles, M. B. and Huberman, A. M. (2010). Qualitative Data Analysis: A Sourcebook of New Methods. Jakarta: UI Press.

Modul Pendidikan Inklusi. (2019). Identifikasi Kesulitan Fungsional dan Penyusunan PBS (Profil Belajar Siswa). INOVASI

Patton, M.Q. (1980). Qualitative Evaluation Methods. Beverly Hills, CA.: Sage Publication.

Peraturan Mendiknas Nomor 70 tahun (2009). tentang Pendidikan Inklusif bagi Peserta Didik Yang Memiliki Kelainan dan Memiliki Potensi Kecerdasan dan/atau Bakat Istimewa.

Purwanto. (2007). Pendidikan Anak Berkebutuhan Khusus. Direktorat Jenderal Pendidikan Tinggi: Departemen Pendidikan Nasional.

Roza, A. \& Rifma (2020). Perencanaan Pembelajaran Anak Berkebutuhan Khusus Dalam Majamen Sekolah Inklusif. (JKPD) Jurnal Kajian Pendidikan Dasar. 5 (1), p. 61-69.

Setiawan, H., Aji, S. M. W., \& Aziz, A. (2020a). Tiga Tantangan Guru Masa Depan Sekolah
Dasar Inklusif. BRILIANT: Jurnal Riset dan Konseptual. 5 (2), p. 241 - 251. DOI: http://dx.doi.org/10.28926/briliant.v3i4.4 $\underline{58}$.

Setiawan, H., Oktaviyanti, I., Jiwandono, I. S., Affandi, L. H., Ermiana, I., \& Khair, B. N. (2020b). Analisis Kendala Guru Di Sdn Gunung Gatep Kab. Lombok Tengah Dalam Implementasi Pendidikan Inklusif. Didaktis: Jurnal Pendidikan dan Ilmu Pengetahuan. 20 (2) p. 169 - 183. DOI: http://dx.doi.org/10.30651/didaktis.v20i2. $\underline{4704}$.

Saputra, A. (2016). Kebijakan Pemerintah Terhadap Pendidikan Inklusif . GOLDEN AGE Jurnal Ilmiah Tumbuh Kembang Anak Usia Dini. 1 (3), p. 1-13.

Surat Direktur Pembinaan Pendidikan Khusus Nomor 3179/D6.1.1/PR/2019 tanggal 22 Agustus 2019 perihal Permbuatan Profil Belajar Siswa Pada Satuan Pendidikan Penyelenggara Pendidikan Inklusif.

Swassing, R. H. (1985). Teaching gifted children and adolescents. CE Merrill Publishing Company.

Ummah, D. M. \& Agustan A. (2018). Analisis Kesulitan Belajar pada Anak Berkebutuhan Khusus (ABK) Di SMA Negeri 10 Kota Ternate. Jurnal Bimbingan dan Konseling Terapan .Vol 2 No 1, 3240. 